\section{Business group internationalization: choosing a host country according to institutional distance}

\author{
Marina A. B Gama \\ Jeferson Lana \\ Cyntia Calixto
}

Getulio Vargas Foundation, Sao Paulo Business Administration School - EAESP, Sao Paulo, SP, Brazil

\author{
Rodrigo Bandeira-de-Mello 12 \\ ${ }^{1}$ Girard School of Business, Merrimack College, North Andover, \\ $M A$, United States of America \\ ${ }^{2}$ Getulio Vargas Foundation, Sao Paulo Business \\ Administration School - EAESP, Sao Paulo, SP, Brazil
}

Received on

$12 / 14 / 2015$

Approved on

07/07/2016

\section{Responsible editor:}

Prof. Dr. João Maurício Gama

Boaventura

\section{Evaluation process:}

Double Blind Review

\begin{abstract}
Purpose - This research analyzes to what extent committing resources to the internationalization of family business groups is related to the institutional distance of the host country.
\end{abstract}

Design/methodology/approach - We used OLS panel data with fixed effects.

Findings - We identified that family business groups decide to internationalize themselves committing fewer resources to countries that present a positive institutional distance, and that are more institutionally developed than the country of origin. On the other hand, when family business groups choose to expand abroad committing more resources, they tend to invest in countries with a negative institutional distance, and that are less institutionally developed than the country of origin.

Originality/value - Our main contribution to existing theory on internationalization of family business groups is to test the relationship between the level of resource commitment by family business groups in their international expansion and the institutional distance between the country of origin and the host country.

Keywords - Family business groups; internationalization; resource commitment; institutional distance.

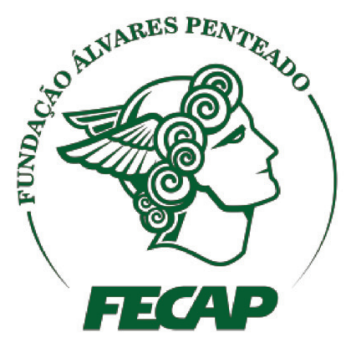

Review of Business Management

DOI: $10.7819 /$ rbgn.v18i61.2894 


\section{Introduction}

This article analyzes to what extent the commitment of resources in the internationalization process of a family business group is associated to the host country's institutional distance. Previous studies indicated a number of advantages and disadvantages in the internationalization of family business groups. Among the disadvantages is the fact that family business groups have rooted within their affiliates institutional characteristics that are specific to their home country, thus hindering their adaptation when there is internationalization to countries with different institutional characteristics (Pedersen $\&$ Stucchi, 2015). Regarding advantages, we can highlight the fact that being affiliated to a group is a way of overcoming institutional weaknesses such as fragile regulations, breakdowns in infrastructure and a failure to fulfill contracts. Group-affiliated firms benefit from financial support and from information for the internationalization process, while also making use of family business groups' influence on the government of the country of origin (Ghemawat \& Khanna, 1998; Yaprak \& Karademir, 2010). Furthermore, there is evidence that family business groups internationalize more quickly than non-affiliated firms, expanding to a higher number of countries, and their entry generally involves greater resources (Yaprak \& Karademir, 2010). However, there is a lack of definitive evidence concerning the decisionmaking process regarding resource commitment, or whether this decision is associated to the institutional level of the host country, since institutions play a relevant role in the establishment and development of family business groups. As such, this article seeks to contribute to existing theory on the internationalization of family business groups, testing if the choice for greater or lesser resource commitment in the internationalization of affiliated firms is associated to the institutional distance between the country of origin and the host country.
Considering that the development of firms depends on the business environment to which they belong (Williamson, 1981), we can understand the growth of family business groups from an institutional perspective. In order to reduce transactions costs in markets with weak institutions, groups diversify and integrate vertically. As well as performing transactions amongst themselves, these integrated firms are able to overcome fragile institutional contexts by doing so (Khanna \& Palepu, 1997, 1999; Yiu, Lu, Bruton, \& Hoskisson, 2007). Thus, the creation of this intragroup market provides support to affiliated firms during their expansion into different countries, regardless of their institutional distances. The term "institutional distance" designates a difference or similarity between home and host countries in terms of institutional environments (Kostova, 1999). Measuring institutional difference is important to understanding the type of entry mode strategies that can be matched to such distance, so as to ensure firms abroad have a competitive edge (Hernandez \& Nieto, 2015).

For this analysis, we used Brazil as the research sample. Brazil was chosen due to its expressive representativeness in terms of family business groups; the 200 biggest groups represented $52.6 \%$ of the Gross Domestic Product in 2012. Also, being a country with weak institutions, family business groups use this "disadvantage" to grow and diversify. Moreover, Brazil holds an average ranking position according to the Worldwide Governance Indicators (WGI), which increases the possibility of its comparison with other nations on that list. As such, the annual ranking from Valor 200 Grandes Grupos was used to compose a sample of 38 groups with international operations. Using these 38 family business groups as a starting point, about 500 affiliated firms were located abroad. These subsidiaries were used in a hypothesis test through panel data and fixed effects regression.

Results show that decisions by family business groups, in terms of resource commitment 
to internationalize, are associated to the institutional distance of the host country. Based on the assumption that the degree of resource commitment comes prior to the choice of a host country, family business groups tend to internationalize with less resource commitment - herein considered a commercial office - to countries that are more developed than the home country. However, when they choose to internationalize with higher resource commitment - in this study referring to a manufacturing plant - family business groups choose countries that are less developed than their home countries.

\section{Theoretical foundation}

\section{I Family Business Groups}

Family business groups are a specific organizational form (Khanna; Yafeh, 2007) and, despite being part of developed markets, as is the case of Italy and Sweden (Chang, 2006; Khanna \& Yafeh, 2007), they dominate private sector activities in the majority of emerging markets around the world (Khanna \& Palepu, 2000a). These groups are given different names in different countries. In South Korea, for example, they are called cheabols; in Japan, keiretsu; in South America, grupos económicos; and, in Russia, oligarchs (Granovetter, 1994). So far, there is no clear consensus in literature about the definition of family business groups (Cuervo-Cazurra, 2006; Khanna \& Rivkin, 2001). Definitions vary from country to country, but the most usual definitions are the following: (i) in a broader approach adopted by Sociology, business groups are a series of firms that are formally or informally connected to each other (Granovetter, 1994); (ii) the other approach, referring to Economics, is more specific and suggests that family business groups are a collection of formally independent firms, although their administrative and financial aspects are often jointly controlled, and often by a family (Chang \& Hong, 2002). Lastly, the definition used in this article is the one suggested by Ghemawat and Khanna (1998) and Khanna and Palepu (1997), in which business groups are legally independent firms, under family control, that operate through a range of industries and, mostly in emerging markets (Ghemawat \& Khanna, 1998; Khanna \& Palepu, 1997).

In regards to organizational structure, family business groups vary greatly. Some are diversified, while others are more vertically integrated (Khanna \& Yafeh, 2007). According to Schneider (2009), family business groups diversify so as to improve economic return through an economy of scope and also to reduce the risk of managerial volatility. For example, the average of sectors to which Chilean groups belong is around 5.6. In India, they belong to 4.2 sectors, and, in the Philippines, 3.5 sectors (Khanna \& Yafeh, 2007). Additionally, a recent study showed that, in Brazil, diversification of family business groups is at around 4 sectors per group (Costa, Bandeira-de-Mello, \& Marcon, 2013). Concerning vertical integration, there are groups that belong to different and correlated industries. For example, family business groups that operate in the agricultural sector have an office that trades agricultural products. Vertical integration also varies among countries. For example, Philippine groups are more vertical than Indian groups, which, in turn, are more vertical that Mexican groups (Khanna \& Yafeh, 2007). In respect to ownership and control, there are vertically controlled groups - pyramidal, and the horizontally controlled (Khanna \& Yafeh, 2007). Essentially, family business groups are pyramidal (La Porta, Lopez-de-silanes, \& Shleifer, 1999; Morck, Shleifer, \& Vishny, 1988; Morck $\&$ Yeung, 2003) and, by means of the pyramid structure, the firm directly and indirectly controls the affiliated firms. Through this, families always control the vote in all group firms, even when they do not necessarily own them (Morck \& Yeung, 2003).

It is possible to understand the expansion of family business groups through Transaction Cost Theory (Williamson, 1981). This theory suggests that development of the firm depends 
on the institutional environment in which it is inserted. When institutional failure occurs, a transaction economically profitable to both parts is not established, since the costs of each transaction outweigh the benefits (Williamson, 1981). Transaction costs are high because rules are not followed; there are imperfect contracts and legislations, when compared to transactions costs in developed countries (Khanna \& Palepu, 1997; Khanna \& Rivkin, 2001). For example, in emerging markets, the financial sector is characterized by limited transparency, weak corporate governance, and control. Financial funds, business analysts and venture capital, the intermediaries, are not always involved in the processes. Moreover, regulation has not been fully developed or is not strong enough to ensure that rules are obeyed (Khanna \& Palepu, 2000a).

As proposed in the definition, business groups are normally family-ruled and usually developed in markets with high transaction costs (Hoskisson, Eden, Lau, \& Wright, 2000). A reduction of transaction costs is possible due to the fact that groups diversify, so they can do better business among the group-affiliated firms and overcome the fragile institutional context (Khanna \& Palepu, 1997, 1999; Yiu et al., 2007). As a result of the previously presented weak conjectures and internal transactions, family business groups create capital, production and work markets within the group. For example, many family groups have their own banks, performing transactions with affiliated firms, as Banco Original, part of Grupo JHS\&F, or Banco Moneo, part of Marcopolo. Another example is uncovered in the job market, in which groups seek to exchange their professionals among the different affiliated firms, instead of hiring someone from the market. In this sense, Hyundai business group developed a technical training process and a research institute to be used by all group-affiliated firms, thereby permitting the use of the same professional in different group firms (Khanna \& Yafeh, 2007).
The establishment of an internal market, within the family business group, provides support to affiliate firms, both in their expansion in the domestic market, described in the previous paragraph, and in terms of international expansion. Regarding the international expansion, there are both disadvantages and advantages associated to group-affiliated firms (Pedersen \& Stucchi, 2015; Yaprak \& Karademir, 2010). The disadvantages are related to the fact that the group carries deeply rooted traits that are specific to their home country. Affiliated firms incorporate the characteristics of emerging markets (wherein groups are more common) and, internally, face aspects such as protectionism, inefficiency, and bureaucracy. Furthermore, as affiliates usually enjoy a favorable position in the internal market, this may discourage their drive for internationalization, as they may not attain a similar position in the international market (Pedersen \& Stucchi, 2015). As such, the institutional characteristics of the home country may act as a demotivating factor in terms of the internationalization of group-affiliated firms.

Furthermore, the advantages are related to the fact that family business groups are able to deal with the institutional breakdowns of home countries and, through this, have more experience in dealing with unstable institutional environments. In this regard, being part of a family business group provides the affiliate firm an advantage in comparison to all the other domestic firms, not only in contact with suppliers and distributors, but also due to the fact that family business groups have close ties to governmental agencies (Yaprak \& Karademir, 2010). These groups have the power to influence politicians and may generate regulatory distortions for their own benefit (Ghemawat \& Khanna, 1998). BeckerRitterspach and Bruche (2012) highlighted the central role of affiliation as a way to access internal and external resources and to develop capacities for the creation of internationally exploitable assets. In the case of groups that originate from emerging economies, Lin (2014) highlights the 
relevance of their contacts with external markets. These contacts facilitate international expansion for affiliates, if compared to unaffiliated firms (Lamin, 2013). Moreover, sharing information and experiences stimulates learning and imitation among group firms and reduces uncertainty when it comes to unexplored markets (Borda-Reyes, 2012).

Thus, the support provided by the family business group in the internationalization of its affiliated firms, motivate them to internationalize faster, into a wider range of countries and with greater resource commitment, when compared to unaffiliated firms (Yaprak \& Karademir, 2010). However, when institutional changes occur in the home country, the speed of the internationalization process may be negatively affected (Kumar, Stucchi, \& Kundu, 2012), that is, institutional factors directly impact the internationalization of affiliated firms. Regarding the commitment of resources , firms affiliated to a family business group tend to invest more resources in the home country than unaffiliated firms (Yaprak \& Karademir, 2010). However, so far there is no accurate evidence about whether the existing difference between the institutional development of the host and the home country affects the commitment of resources of affiliated firms. Therefore, this is the theoretical gap that this article seeks to fill.

\subsection{Host country selection based on institutional distance}

According to institutional theory, the external context is responsible for dictating the rules of the game (North, 1990). The mechanisms that ensure compliance with these rules are the legislative, executive and judicial institutions, along with bureaucratic government issues, not to mention the obligation of fulfilling contracts and laws (Williamson, 2000). Through institutions it is possible to do business, secure agreements and resolve problems more efficiently. Institutions are composed of formal and informal rules. The formal rules are laws, the constitution and regulations. The informal rules are linked to people's behavior, such as, for example, habits not specified accurately in the rules and laws (North, 1990). High quality institutions are necessary to economic growth, as they facilitate efficient operations among individuals and firms. In particular, institutional efficiency is a result of the coherent execution of regulations (La Porta et al., 1999) and tends to promote the firm's good performance and export growth rates (LiPuma, Newbert, \& Doh, 2013). In emerging markets, however, institutions are often weak, of poor quality and subject to legal, political, governmental, social and cultural, technological and security issues. As such, the domestic environment makes firms more selective when choosing their host countries (Mishra \& Daly, 2007). Thus, institutional differences may influence the objective of firms' internationalization (Moore, Payne, Bell, \& Davis, 2015), as well as the entry mode in the new markets (Xu \& Shenkar, 2002), the adoption of policies and practices (Kostova \& Roth, 2002) and their performance (Zaheer \& Mosakowski, 1997).

One way to assess institutional differences is the institutional distance, which evaluates the differences or similarities between the home and the host country in terms of their institutional environments (Kostova, 1999). Generically speaking, institutional difference is the individual and collective difference among regulatory, normative and cognitive aspects of the home and host countries (Moore et al., 2015). Estimating this distance is important, as it permits to understand which entry mode strategy can be matched to the institutional distance, so as to guarantee a competitive edge to firms abroad (Hernandez \& Nieto, 2015). Furthermore, through this measure, it is possible to analyze firms' level of complexity in emerging markets, as institutions are usually weaker and more complex in said markets (Moore et al., 2015). In this sense, there is evidence that the greater the institutional distance, the more difficulty the foreign subsidiary will face in instituting legitimacy and transferring routines to its headquarters (Kostova \& Zaheer, 
1999). Xu and Shenkar (2002) proposed that multinationals choose less control over their subsidiaries abroad when the environment of the host country presents an institutional system that is very different from the home country, though they do choose majority control when the institutional system is similar. Another study showed that the probability of an investment in a greenfield-type expansion increases when the regulatory distance between countries is greater (Ionascu, Meyer, \& Erstin, 2004). Thus, a larger institutional distance would discourage the entry of external capital, but the detrimental effect is mitigated if the host country holds substantial resources (Aleksynska \& Havrylchyk, 2013).

Hernandéz and Nieto (2015) showed that institutional distance has directions: negative distance, when a subsidiary is installed in a country with institutions that are worse than the home country; and positive distance, when the subsidiary is established in a country with better regulatory institutions than the home country. Thus, internationalization for countries with lower regulatory development levels is related to entry modes that require lesser resource development. Entry into countries with more elevated levels of regulatory development is related to the entry modes that calls for greater resource commitment (Hernandez \& Nieto, 2015). Therefore, we suggest that the direction of institutional distance is important when deciding on resource commitment in international expansion. However, when the subsidiary of a multinational is affiliated to a family business group, what happens in relation to the commitment of resources and institutional distance? The previous studies did not show evidence of how family business groups internationalize in terms of institutional distance.

It is important to note that institutional issues may be determinant to the internationalization of family business groups, once affiliated firms incorporate the institutional characteristics of emerging markets. This may lead to a certain amount of difficulty in adapting to foreign markets, in the case of expanding into developed markets (Pedersen \& Stucchi, 2015). Additionally, the fact that family business groups are able to cope with the institutional flaws of the home country means they have more experience in dealing with unstable institutional environments (Pedersen \& Stucchi, 2015). Furthermore, there is evidence that family business groups influence national policy for their own benefit (Ghemawat \& Khanna, 1998; Morck \& Yeung, 2003). Thus, we propose that family business groups choose to commit more resources in countries with a negative institutional distance, as they have more experience in dealing with volatile institutional environments, similar to those in their home countries. Consequently, family business groups will commit fewer resources in countries with a positive institutional distance, that is, countries that are more institutionally developed, since their affiliates incorporate the characteristics of the domestic market and face difficulty in dealing with more developed markets.

Thus, we understood that the choice of the host country in terms of institutional distance is relevant to the internationalization of family business groups. What antecedes this choice is the level of resource commitment that the group-affiliated firm will hold in its international expansion, which may be in the form of a commercial office, meaning low resource commitment, or even a manufacturing plant, meaning high resource commitment.

\subsection{Hypothesis development}

Family business groups are more common in emerging markets (Khanna \& Palepu, 2000a). They develop and grow due to the institutional flaws of the home country (Khanna \& Palepu, 2000a) and transact among group-affiliated firms, whenever this is most advantages in terms of transactions costs (Williamson, 1981). Affiliated firms internationalize with advantages in relation to unaffiliated firms, as they receive support from the connections the family business group has with governments, banks and institutions (Pedersen \& Stucchi, 2015). In addition, as institutions play a relevant role in the establishment and development of family business groups; affiliated firms are marked by the institutional characteristics of the home country, such as, for example, protectionism, 
inefficiency and bureaucracy. All the same, as they occupy a favorable position within the market, they may be less motivated to internationalize to countries very different in institutional terms (Pedersen \& Stucchi, 2015). Therefore, it is proposed that family business groups choose to internationalize to institutionally more distant countries with less resource commitment as a way to learn about that institutional environment. However, through this approach they become less exposed to risk by committing resources, as they do not develop sufficient skills to deal with more developed institutional environments. In this way, the group faces greater difficulty in making connections with governments, gaining access to financing and forming relationships with local institutions, as they differ greatly to the reality of the home country. Thus, we propose the following hypothesis

H1: A lower degree of resource commitment in the internationalization of a family business group is positively associated to the institutional distance between home and host countries.

As the institutional issue is relevant in the configuration and growth of family business groups, the firms affiliated to these groups deal with a financial sector lacking transparency, with the regulation of underdeveloped countries, with weak commitment to fulfilling contracts and failure to comply with local laws (Khanna \& Palepu, 2000a). As a result, a weak institutional context induces family business groups to create a market within the actual group, grow and diversify in environments with inadequate institutional development. Being part of a family business group thus creates a competitive edge for the affiliate firm, as the groups usually have an influence on policy and are proficient in dealing with volatile institutional environments. As such, we propose that family business groups chose to internationalize with greater resource commitment to countries with a negative institutional distance in relation to home countries, that is, to less institutionally developed countries, as they find it easier to deal with the institutions of that country, seeing as though they already do so efficiently in their home countries. Thus, we propose the following hypothesis:

H2: $A$ higher degree of resource commitment in the internationalization of a family business group is negatively associated to the institutional distance between home and host countries.

Figure 1 shows the relationship between the variables proposed in hypotheses 1 and 2 .

Hypothesis 1:

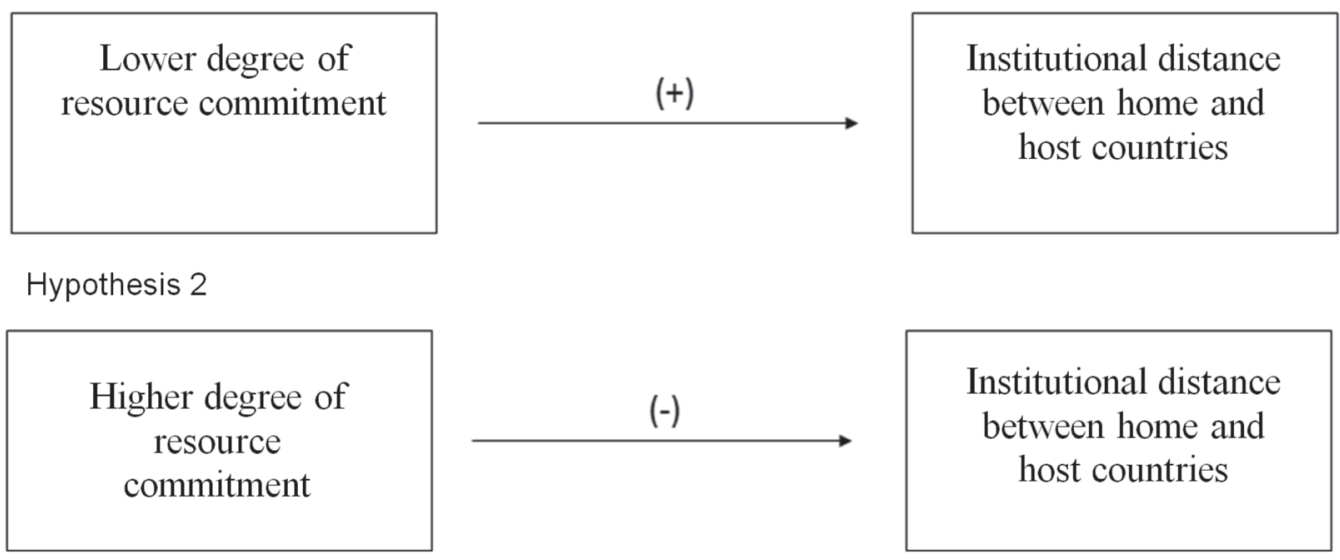

Figure 1: Model of the relationship among variables

Source: authors. 


\section{Methods}

\section{I Data}

Collecting data on family business group internationalization to test our hypothesis was a major challenge in Brazil, as the information on business group affiliated firms is difficult to obtain. In this article, data was collected through multiple sources, in order to guarantee access to the volume and quality necessary to test models on an unprecedented longitudinal database, thereby constructing a panel database. A longitudinal of data offers better estimators, as it provides insight on how the phenomenon behaves over time. Also, firms tend to internationalize year after year (often with more than one international expansion per year) and, thus, longitudinal data can offer better explanations to the proposed models.

Regarding the data of Brazilian family business groups, we collected through Valor Grande Grupos. Data was captured from the 2001 to 2011 editions, a period that historically represents an intensive internationalization process among Brazilian firms, due to a series of promarket reforms and favorable international conditions. The publication ranks the top 200 Brazilian business groups. The group's gross earnings are used for the rank selection format. Valor Grandes Groups is an annual publication available on the newspaper Valor Econômico, Brazil's leading periodical on business and finance. Information gathered from Valor Grandes Grupos has previously been used in other academic studies (Aldrighi \& Postali, 2010; Costa et al., 2013; Xavier, Marcon, \& Bandeira-de-Mello, 2013). Data showed that, among the top 200 Brazilian business groups, only 38 run foreign operations. In the period from 2001 to 2011 , these 38 internationalized family business groups were responsible for establishing 541 affiliated firms abroad, in over 50 different countries.

Besides the annual publication of Valor Grandes Grupos, the sample was selected from a collection of secondary data sources. Among these sources are: (i) Orbis Database - through which it was possible to access each group and verify their international activities (whether they ran foreign operations and information about the international subsidiary); (ii) the websites of each family business group - from where we gathered information regarding the group's history and decisions on internationalization (iii) Worldwide Governance Indicators (WGI) $-A$ World Bank database, providing information on the institutional development of the countries analyzed. It is important to note that researchers from different fields, such as Economics, Political and Social Sciences, have diverging philosophies and concepts regarding the institutional environment and, as such, they attribute different values to the range of components that form the concept of institutions (Mudambi \& Navarra, 2002). In this study, we used the governance indicators obtained from Worldwide Governance Indicators to show the institutional development of a country. In total, there are six key dimensions of governance published each year through WGI for a list of 215 countries, and which will be explained further on. Finally, the last data source was (v) Economatica - which provided information about diversification, accounting and financial information. The final sample is comprised of 361 observations, approximately 33 groups per year, given that some groups may have formed after 2001 or terminated their operations prior to 2011. As each group likely has more than one affiliated form abroad per year, this explains the reasons why the number of observations is less than the number of foreign affiliated firms. The idea was to quantify the structure of family business groups in the host country, by the number of foreign affiliated firms and the type of foreign affiliated form manufacture, financial institution, distribution centers and commercial offices. Thus, the study's unit of analysis is the group and its structure and not the subsidiary alone.

\subsection{Variables}

\subsection{Dependent variable}

This article considers the institutional distance between Brazil and the countries where family business groups have affiliates as being a 
dependent variable. All the information relative to the perception of the institutional quality of the countries was collected from World Bank data using the so-called Worldwide Governance Indicators (WGI). The database offers a ranking on the perceived institutional quality of countries. Position of each nation corresponds to the percentile at which the country is found among 215 others studied by the World Bank, on a scale that varies from 0 to 100 . Brazil has usually featured between 40 and 60 over the years of research, based on a series of assessment dimensions. For example, if in a given year Brazil features at 45.03 , this means that the country presents greater institutional development than $45.03 \%$ of the countries in the database. Thus, by knowing the position of each country, it is possible to calculate the distance between them and Brazil. The formula is presented as follows: Institutional Distance $=$ [Ranking of host countries] - [Brazil Ranking]

This simple subtraction is able to determine the distance (in positions) between Brazil and the other countries. Positive institutional distance values indicate that the foreign affiliated firm was set up in a country with institutions better developed than the Brazilian ones. For example, an institutional distance of +40.02 indicates that the affiliated firm is hosted in country ranked $42.02 \%$ higher than Brazil indicting more developed institutions. In the case of multiple foreign affiliated firms established in the same year, an average was used for the group's institutional distance in that year (adding the positions of the countries and dividing the total by the number of foreign affiliated firms).

WGIs indicators are composed by six dimensions on the perception of institutional quality. It is worth reiterating that all these indicators are related to the country's governance:

(i) Voice and Accountability: reflects the perception of amplitude that a citizen of the country has to participate in the selection of his/her government, as well as the freedom of expression, freedom of association and freedom of the press; (ii) Political Stability and Absence of Violencel Terrorism: Political Stability and Absence of Violence/Terrorism measures perceptions of the likelihood of political instability and/or politically motivated violence, including terrorism;

(iii) Government Effectiveness: measures the quality of public services, the quality of the civil service and its independence from political pressures, the quality of policy formulation and implementation, and the credibility of the government's commitment to its stated policies;

(iv) Regulatory Quality: captures perceptions of the ability of the government to formulate and implement sound policies and regulations that permit and promote private sector development.

(v) Rule of Law: This indicator measures the extent to which individuals and firms have confidence in and abide by the rules of society; in particular, it measures the functioning and independence of the judiciary, including the police, the protection of property rights, the quality of contract enforcement, as well as the likelihood of crime and violence;

(vi) Control of Corruption: This indicator measures the extent to which public power is exercised for private grain, including both petty and grand forms of corruption, as well as "capture" of the state by elites and private interests.

All these indicators were grouped in a single factor, treated as the Mean Institutional Distance, represented by the simple arithmetic average of the values of each of the previous indicators, per country and per year. Due to issues of robustness, tests were also undertaken for each of the indicators individually. For each of the six indicators reported by the World Bank, Brazil tends to occupy positions close to the middle, in the period between 2000 and 2011. Below Brazil are the countries with negative institutional distances, ranked with less develop institutions, and above Brazil are those nations with positive 
institutional distances, a group composed by more developed institutions. The fact that Brazil's indexes are close to the middle makes it an especially interesting option for the application of this study, as the number of countries with more or less developed countries tends to be equivalent.

The models in this article were operationalized in accordance with each of the WGIs, in order to determine whether the decision to internationalize Brazilian family groups has a relevant association on measuring the Mean Institutional Distance. Model 1.1 to 1.6 consider the Mean Institutional Distance as a dependent variable. Models 2.1 to 2.6 consider each of the six WGIs as dependent variables. Tests with disaggregate dependent variables contribute to the robustness of results found in models 1.1 to 1.6, since they identify the aggregate and individual effect found.

\subsubsection{Independent variable}

3.2.2.I Type of affiliated firm in the host country

Hypotheses 1 and 2 tests are related to the type of affiliate firm installed in the host country. As such, foreign affiliated firms were characterized as: (i) manufacturing plants and (ii) commercial offices. These variables were captured through the corporate group websites, Orbis and the Valor Grandes Grupos annual publication. They were measured using the total number of foreign affiliated firms that family business groups establish in each category (manufacturing plant and commercial office) per year. Through this variable, it is possible to capture the affiliate firm's degree of resource commitment in its internationalization.

\subsubsection{Number of foreign affiliated firms}

Through using the number of its subsidiaries, it is possible to measure how the internationalization process of a family business group occurs. Data was thus collected on the number of affiliated firms in different host countries, using databases such as: (i) Orbis; (ii) corporate group websites; (iii) statements and publications by the firm. This variable was employed in certain studies for example, in Dau (2012), who used it to measure the number of foreign subsidiaries held by the firms.

In total, data was obtained on 81 different countries, representing 541 foreign affiliated firms. According to the presented theoretical model, it is expected that the number of foreign affiliated firms linked to Brazilian family business groups can explain greater institutional distances adopted by new foreign affiliated firms.

\subsubsection{Control variables}

\subsubsection{Diversification}

Diversification was gauged using market indicators from the Economatica database, taking from it sectoral information with 55 levels of classification, used by the Brazilian Institute of Geography and Statistics (IBGE). Each of the firms affiliated to the corporate groups was analyzed, based on Valor Grandes Grupos, and classified in 33 different sectors. The diversification variable is considered one of the leading characteristics of family business groups and, as such, control of it is considered important (Ghemawat \& Khanna, 1998; Khanna \& Yafet, 2005; Costa et al. 2013).

\subsubsection{Vertical integration}

The same classification used by the IBGE was used to calculate vertical integration followed by the article by Khanna and Yafet (2005) and also the proxy generated by the work of Costa, Bandeira-de-Mello and Marcon (2013). To achieve this, an intra-sectoral technical coefficient matrix was used, representing production values in Brazil, activity by activity. Using this table, sectors were identified, along with which groups belong to each sector (55 levels). The vertical integration variable is considered one of the leading characteristics of family business groups and, as such, control of it is considered important 
(Ghemawat \& Khanna, 1998; Khanna \& Yafet, 2005; Costa et al. 2013).

\section{$3 \cdot 2 \cdot 3 \cdot 3$ Revenue}

In this variable, we considered the total gross annual revenue for each family business group. The Total Assets and Net Profit were also tested, although these variables present expressive multicollinearity with diversification. Lastly, models were tested that use revenue as representative of the size of the family business group (variable transformed into a logarithm). This variable is used to control the size of the family business group and is commonly used in strategy studies (Inoue, Lazzarini, \& Musacchio, 2013).

\subsection{Analysis procedures and model specification}

Using data descriptive statistics, we assessed information such as: the main destination for international expansion by business groups and the type of affiliated firm established abroad. This information was important to understand these groups' extension and the type of investment they are looking for in those particular countries. Following this phase, the correlation matrix was studied for each of the main variables. Results are presented in Table 2 . The correlation matrix helps prevent the presence of variables with elevated correlation coefficients $(>0.70)$, which may lead to problems such as multicollinearity and estimation errors.

Both hypotheses, 1 and 2, were tested through the use of multiple linear regression, in a non-observable and fixed effects model. We understand that the choice seeks to control non-observable variables and non-observable heterogeneities (Allison, 2009), even though it is not able to control the non-observable variables that present change over time. As such, fixed effects help control all the non-observable variables that remain unchanged over time, such as the year of establishment, sector and specific characteristics of the firm. Multiple linear regression represents an important tool for testing covariance among the variables that, in some cases, may be interpreted as causal effects. In the procedures and outline of this study, we attempted to develop tests in a way to optimize the possibility of finding causal effects in the coefficients. However, it is understood that these variables may present correlation with the term of error, generated due problems in endogeneity, for example. The final model is presented by:

$I D_{i t}=\beta_{1}+\alpha_{i}+u_{i}+N_{o S} S_{i t}+$ Type $_{i t}+\Sigma \beta$ Controls $_{i t}+\varepsilon_{i t}$

In this equation, means the Institutional distance of the affiliated firm established in a foreign country compared to Brazil (whether the average or any of the six indicators that comprise the WGI base). Models 1.1 to 1.6 use the mean institutional distance as a dependent variable, while models 2.1 to 2.6 use each of the six variables measured by WGIs. The variable represents the number of foreign affiliated firms per family business group. The variable represents the type of established affiliated firm and, lastly, refers to the controls added to the models.

Robust coefficients for estimators were used to control heteroscedasticity. Multicollinearity was analyzed through the Variance Inflation Factor (VIF) and cases in which the VIF exceeded a 5.00 value were eliminated. Finally, the residues of each of the models were analyzed, seeking evidence of non-linearity. All models were tested with the help of Stata MP 13.1 software.

\section{Results}

Presenting a summarized look at the data, Table 1 shows the descriptive statistics of the variables used in this article. Even though many of the variables present 428 observations (8 groups over 11 years), the models present a total 362 valid cases. This reduction is due to the lack of information for certain years and family business groups analyzed. It is worth noting that, among all the institutional distance variables (average and individually in the six indicators), the minimum 
value was -56 , while the maximum was +61 . As previously reported, the outreach of distance in the WGI variable ranges between 0 and 100 . However, in the majority of cases, Brazil presented numbers close to 45 and 55 . Thus, values found between -56 and +61 were unsurprising. Table 1 presents longitudinal averages, standard deviation, minimum and maximum values, asymmetry and kurtosis of the variables discussed earlier.

Table 1

Descriptive Statistics

\begin{tabular}{|c|c|c|c|c|c|c|c|c|}
\hline & Variable & Notes & Average & $\begin{array}{c}\text { Standard } \\
\text { Dev. }\end{array}$ & Min & $\operatorname{Max}$ & Asymmetry & Kurtosis \\
\hline (1) & Mean Institutional Distance & 428 & 3.2590 & 13.8653 & -45.6558 & 46.9529 & 0.8586 & 4.8704 \\
\hline (2) & Control of Corruption & 428 & 2.1546 & 14.7693 & -56.0976 & 47.3171 & 0.2844 & 5.1674 \\
\hline (3) & Rule of Law & 428 & 5.2974 & 17.1597 & -53.5545 & 61.7225 & 1.3256 & 5.1022 \\
\hline (4) & Regulatory Quality & 428 & 2.7625 & 14.8447 & -51.1962 & 45.0980 & 0.2717 & 5.3618 \\
\hline (5) & Government Effectiveness & 428 & 4.8512 & 14.4165 & -48.2927 & 48.5366 & 0.8078 & 5.2347 \\
\hline (6) & Political Stability & 428 & 3.8014 & 14.7461 & -52.4038 & 57.6923 & 1.1427 & 6.0575 \\
\hline (7) & Voice and Accountability & 428 & 0.6867 & 14.2166 & -56.8075 & 44.9519 & -0.6368 & 7.6913 \\
\hline (8) & Num. of foreign affiliated firms. & 428 & 0.8224 & 1.9897 & 0.0000 & 27.0000 & 7.0110 & 78.7697 \\
\hline (9) & Manufacturing & 428 & 0.3621 & 1.1087 & 0.0000 & 13.0000 & 6.7140 & 64.4933 \\
\hline (10) & Commercial & 428 & 0.1192 & 0.4665 & 0.0000 & 5.0000 & 5.5213 & 42.2839 \\
\hline (11) & Diversification & 363 & 1.4973 & 0.7432 & 0.0000 & 3.1355 & -0.3662 & 2.5519 \\
\hline (12) & Vertical Integration & 363 & 0.2881 & 1.6039 & -3.9391 & 5.3091 & 0.2101 & 3.3169 \\
\hline (13) & Revenue & 377 & 8.6704 & 1.4091 & 5.7491 & 12.6321 & 0.3964 & 2.5667 \\
\hline
\end{tabular}

Table 2 presents the correlation matrix. Data shows a strong and significant correlation among all the institutional distance variables (Table 2 , lines 1 to 7 ), with $\beta>0.66(p<0.05)$, which permits aggregate treatment. Following the idea that the number of foreign affiliated firms shows a consistent and positive relation with institutional distance, the coefficients of Table 2 (line 8) present values that are in accordance with expectations. The same consistency is found as to commercial office-type affiliated firms, referring to hypothesis 1 (Table 2 line 10). Institutional distance associating manufacturing plant-type affiliated firms did not present a significant initial relationship (Table 2, Line 9: $p<0.05$ ). Both diversification and vertical integration variables presented a significant and negative correlation (Table 2, line 12: $p<0.05$ ) and are positively related to the revenue variable. Independent variables do not present a relevant significant relationship, which is an important condition in avoiding multicollinearity. 
Business groups internationalization: choosing a host country according to institutional distance

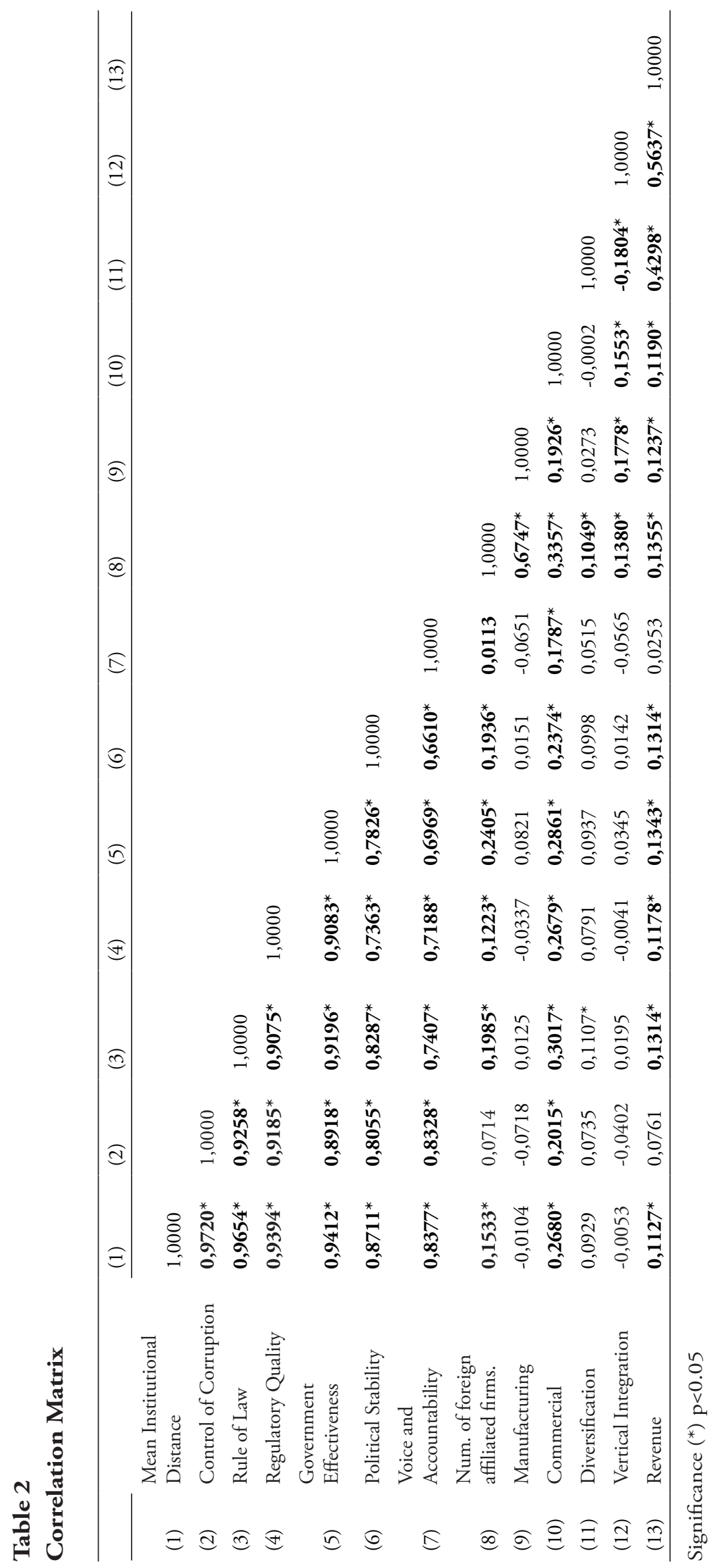


The hypotheses tested the relationship between the commitment of resources by family group-affiliated firms and the choice of host country in terms of institutional distance. To test these hypotheses, Table 3 used the mean institutional distance as a dependent variable, considering that aggregation of the six WGIs in a single variable and then calculating the actual distances between Brazil's position and the numbers presented by host nations. Hypothesis 1 suggests that a commercial office affiliated firm, which expends fewer resources, is positively correlated to the choice of the host country measured by institutional distance. And hypothesis 2 states the contrary effect, with regards to manufacturing-type affiliated firms, which commit greater resources.

Table 3

Regression of models 1.1 to 1.6

\begin{tabular}{|c|c|c|c|c|c|c|}
\hline \multirow{2}{*}{ Model } & \multicolumn{6}{|c|}{ Mean Institutional Distance } \\
\hline & Model 1.1 & Model 1.2 & Model 1.3 & Model 1.4 & Model 1.5 & Model 1.6 \\
\hline \multirow[t]{2}{*}{ Num of foreign affiliated firms. } & 0,616 & & & 0,769 & $1,103^{* *}$ & $1,071^{* *}$ \\
\hline & $(0,406)$ & & & $(0,531)$ & $(0,467)$ & $(0,463)$ \\
\hline \multirow[t]{2}{*}{ Manufature } & & $-0,167$ & & $-1,483^{*}$ & $-1,997^{* * *}$ & $-1,966^{* * *}$ \\
\hline & & $(0,561)$ & & $(0,855)$ & $(0,711)$ & $(0,713)$ \\
\hline \multirow[t]{2}{*}{ Commercial } & & & $6,193^{* * *}$ & $5,709^{* * *}$ & $4,906^{* *}$ & $4,973^{* *}$ \\
\hline & & & $(1,781)$ & $(1,877)$ & $(2,038)$ & $(2,054)$ \\
\hline \multirow[t]{2}{*}{ Diversification } & & & & & $-0,200$ & 0,0417 \\
\hline & & & & & $(2,671)$ & $(2,516)$ \\
\hline \multirow{2}{*}{ Vertical Integration } & & & & & $-0,361$ & $-0,189$ \\
\hline & & & & & $(0,906)$ & $(0,926)$ \\
\hline \multirow[t]{2}{*}{ Interaction \# (Div\#Int) } & & & & & 0,00587 & 0,00633 \\
\hline & & & & & $(0,0145)$ & $(0,0147)$ \\
\hline \multirow[t]{2}{*}{ Revenue } & & & & & & $-0,682$ \\
\hline & & & & & & $(1,160)$ \\
\hline \multirow[t]{2}{*}{ Constante } & $2,752^{* * *}$ & $3,320^{* * *}$ & $2,521^{* * *}$ & $2,484^{* * *}$ & 2,618 & 8,083 \\
\hline & $(0,334)$ & $(0,203)$ & $(0,212)$ & $(0,286)$ & $(4,258)$ & $(11,30)$ \\
\hline Notes & 428 & 428 & 428 & 428 & 363 & 361 \\
\hline R-squared & 0,008 & 0,000 & 0,041 & 0,049 & 0,049 & 0,049 \\
\hline Number of Groups & 39 & 39 & 39 & 39 & 38 & 38 \\
\hline EF firms & YES & YES & YES & YES & YES & YES \\
\hline
\end{tabular}

Robust standard errors in parentheses, Significance: ${ }^{* * *} \mathrm{p}<0.01,{ }^{* *} \mathrm{p}<0.05,{ }^{*} \mathrm{p}<0.10$

Hypothesis $\mathrm{H} 1$ is supported both by the evidence noted in Model 1.3 (Table 3: $\beta=6.193$, $p<0.01$ ), when controlled for other variables (such as the number of foreign affiliated firms and revenue). The coefficient maintains its properties with a slight downturn in its explanatory power (Table 3. Model 1.6: $\beta=4.973, p<0.05$ ). Consequently, tests suggest that the less resource commitment - opening a commercial office in the host country - is positively associated to the commercial distance between the home and host countries, in support of hypothesis H1. In other words, it suggests that Brazilian family business groups internationalize to developed countries by means of commercial offices, since risk and investment are lower, and the institutional environment is different from that of groupaffiliated firms. 
Hypothesis H2 argues that the higher commitment of resources - opening a manufacturing plant in the host country - is negatively associated to the institutional distance between the home and host nations. In the case of foreign affiliated firms, the simple linear regression test found no statistical significance (Table 3. Model 1.2: $\beta=-0.167, p<0.05)$. However, when control variables are used, the foreign affiliated firms of the manufacturing plant type present both negative and significant effects. Model 1.6: $\beta=-1.966, p<0.01$; Table 3. Model 1.5: $\beta=-1.997$, $p<0.01)$. In short, these results suggest that, when the institutional distance between Brazil and the host country is negative (indicating countries with less developed institutions), Brazilian family business groups tend to internationalize through affiliated manufacturing plants. These results provide support to hypothesis $\mathrm{H} 2$. That is, there is greater motivation to internationalize when host country institutions are less developed than those of the home country.

Furthermore, the variable for the number of foreign affiliated firms presents a nonsignificant relation in the simple linear model (Table 3. Model 1.1: $\beta=0.616, p<0.05$ ). When the diversification and revenue control variables are used, the test reports a positive and significant coefficient (Table 3. Model 1.6: $\beta=1.1071$, $p<0.05$ ). This result shows that the number of foreign affiliated firms is positively related to the institutional distance. In sum, an increase in the number of foreign affiliated firms allows family business groups to turn to countries with higher institutional development than the home country.

To avoid problems arising from aggregate variables, such as mean institutional distance used in models 1.1 to 1.6 , we opted for a series of robustness tests using each of the six WGIs. Thus, instead of using the mean institutional distances among the rankings for each of the countries and for each of the WGIs reported (Table 4). As such, the tests related to the following models: Control of Corruption (Model 2.1), Rule of Law (Model 2.2), Regulatory Quality (Model 2.3),
Government Effectiveness (Model 2.4), Political Stability (Model 2.5), Voice and Accountability (Model 2.6). Testing the indicators individually is an attempt to reinforce the explanatory power of the model found. Once again, hypotheses 1 and 2 found support for the majority of cases tested. Hypothesis H1 was fully supports (Table 4. Models 2.1 to 2.6), while hypothesis $\mathrm{H} 2$ found support in four out of the six dimensions (Table 4. Models 2.1 to 2.3 and Model 2.5).

These results allowed us to advance with the existing theory on the internationalization of family business groups. Earlier evidence suggests that group-affiliated firms invest more resources in host countries than unaffiliated firms. Our results showed that, depending on the institutional distance between the home and host countries, the commitment of invested resources may be higher or lower.

Regarding the support of hypothesis $\mathrm{H} 1$, we can infer that family business groups internationalize with less resource commitment, that is, through commercial offices, to countries with higher institutional development than found in the home country. This result complies with the findings by Hernandez and Nieto (2015), who affirmed that, the more positive the institutional distance the higher the commitment in the host country. However, the study by these authors looked at firms unaffiliated to family business groups. In the case of family business groups, literature shows that, because affiliated firms have deep-rooted characteristics from their home countries (Pedersen \& Stucchi, 2015) and the majority of them are from countries that face weak institutional development (Khanna \& Palepu, 2000b; Morck \& Yeung, 2003), they run a higher risk by committing resources, since they have not developed sufficient competencies to deal with more developed institutional environments. Based on this result, we may corroborate what was proposed by Kostova and Zaheer (1999). According to the authors, the greater the institutional distance between countries, the more difficult it will be, for subsidiaries, to impress their 
legitimacy and transfer routines between the home and host countries. Incompatibility between family group-affiliated firms and countries with more developed institutional environments leads to greater risk and uncertainty for affiliates, essentially resulting from a lack of knowledge on how to cope within a different institutional environment (Berry, 2006).

Table 4

Regression of models 2.1 to 2.6

\begin{tabular}{lcccccc}
\hline \multirow{2}{*}{ Model } & CofCor & RuOfLw & RegQlt & GofEff & PolSta & VoAcco \\
\cline { 2 - 7 } & Model 2.1 & Model 2.2 & Model 2.3 & Model 2.4 & Model 2.5 & Model 2.6 \\
\hline Num of foreign affiliated & 0.807 & $\mathbf{1 . 7 7 8}^{* *}$ & $\mathbf{1 . 0 3 3}^{* *}$ & $\mathbf{1 . 3 8 2}^{* *}$ & $\mathbf{1 . 4 4 2} \mathbf{2 *}^{* *}$ & -0.0166 \\
firms. & $(0.491)$ & $(0.663)$ & $(0.488)$ & $(0.590)$ & $(0.643)$ & $(0.526)$ \\
\hline Manufacture & $\mathbf{2 . 3 2 0 ^ { * * * }}$ & $\mathbf{- 2 . 8 9 4 ^ { * * * }}$ & $\mathbf{- 2 . 3 1 9 ^ { * * }}$ & -1.465 & $\mathbf{- 1 . 7 6 1 ^ { * * }}$ & -1.035 \\
& $(0.785)$ & $(0.921)$ & $(0.873)$ & $(0.953)$ & $(0.833)$ & $(0.800)$ \\
\hline Commercial & $4.000^{* *}$ & $6.552^{* * *}$ & $5.293^{* *}$ & $4.415^{*}$ & $4.844^{* *}$ & $4.735^{* *}$ \\
& $(1.926)$ & $(2.110)$ & $(2.579)$ & $(2.273)$ & $(2.070)$ & $(2.057)$ \\
\hline Diversification & -0.768 & -0.769 & -0.820 & 1.645 & -1.156 & 2.118 \\
& $(2.773)$ & $(2.772)$ & $(2.398)$ & $(2.113)$ & $(2.899)$ & $(3.394)$ \\
\hline Vertical Integration & -0.521 & -0.173 & -0.391 & -0.0217 & -0.314 & 0.284 \\
& $(1.051)$ & $(1.043)$ & $(0.999)$ & $(0.872)$ & $(0.957)$ & $(1.227)$ \\
\hline Interaction \# (Div\#Int) & -0.00257 & 0.00803 & 0.00712 & 0.00760 & 0.0204 & -0.00258 \\
& $(0.0156)$ & $(0.0140)$ & $(0.0133)$ & $(0.00945)$ & $(0.0161)$ & $(0.0249)$ \\
\hline Revenue & -0.789 & -2.145 & 1.660 & 1.397 & -0.995 & $\mathbf{- 3 . 2 2 2 * *}$ \\
& $(1.265)$ & $(1.364)$ & $(1.178)$ & $(1.067)$ & $(1.481)$ & $(1.432)$ \\
\hline Constant & 9.890 & $\mathbf{2 3 . 4 9 *}$ & -11.01 & -10.97 & 12.46 & $\mathbf{2 4 . 6 4}$ \\
& $(12.15)$ & $(12.99)$ & $(10.74)$ & $(10.09)$ & $(14.82)$ & $(12.59)$ \\
Notes & 361 & 361 & 361 & 361 & 361 & 361 \\
R-squared & 0.034 & 0.073 & 0.050 & 0.062 & 0.059 & 0.037 \\
Number of Groups & 38 & 38 & 38 & 38 & 38 & 38 \\
EF firm & YES & YES & YES & YES & YES & YES \\
\hline & & & & &
\end{tabular}

Robust standard errors in parentheses, Significance: ${ }^{* * *} \mathrm{p}<0.01,{ }^{* *} \mathrm{p}<0.05,{ }^{*} \mathrm{p}<0.10$

Through the support of hypothesis $\mathrm{H} 2$, it is possible to infer that family business groups internationalize with greater resource commitment, that is, through manufacturing plants, to countries with lower institutional development than that found in the home country. There is evidence that a negative institutional distance between home and host countries leads to foreign firms making a lesser commitment in the host country (Hernandez \& Nieto, 2015). However, in the case of family business groups, we may infer that the opposite is true, since the groups are well-versed in unstable institutional environments, as developed in countries with weak institutions (Khanna \& Palepu, 2000; Ghemawat \& Khanna, 1998). Guillén (2000) and Khanna and Palepu (2000a) suggest that family business groups could exist in the absence of developed markets since, in essence, that happens to give their affiliates the opportunity to operate in imperfect markets in terms of capital, production, work and technology. Markets with high levels of corruption (Cuervo-Cazurra, 2008) are subject to unexpected changes in governmental policies 
and government intervention in private business (Slangen \& Tulder, 2009). However, family business groups have the competitive edge of close political connections and, through these, are able to influence home country's policies (Ghemawat \& Khanna, 1998; Morck \& Yeung, 2003; Morck, 2010; Schneider, 2009). Thus, a good understanding of less developed institutions increases the perception of difficulties in the host country and aids the development of the affiliated firm in that country (Håkanson \& Ambos, 2010). Consequentially, it is easier for group-affiliated firms to access less institutionally developed countries, since family business groups have the necessary set of skills to deal with less developed institutions (Pedersen \& Stucchi, 2015). With the lower risk of failure, they choose greater investments.

Moreover, it was possible to verify the knowledge developed over the years in relation to the internationalization of firms affiliated to family business groups. There is evidence showing that, as family business groups increase their number of foreign affiliates, there is a greater trend for them to enter countries with a positive institutional distance, in other words, more developed than the home country. The results found in this study corroborate to what was proposed by Borda-Reyes (2012): the exchange of experience and information among firms part of family business groups stimulates learning and reduces uncertainty in unexplored markets (Borda-Reyes, 2012). Groups gain international experience through their affiliated firms and this ends up being an important resource in expanding internationally (Yang, Jiang, Kang, \& Ke, 2009).

\section{Conclusion}

Our results contribute to extent the knowledge on the literature about family business groups. Previous studies showed that business groups invest more resources in the host country, when compared to group-unaffiliated firms (Yaprak \& Karademir, 2010). However, this article challenged that notion and shows that the decision to commit greater (manufacturing plant) or lesser (commercial office) resources is related to the institutional distance between the home and host countries. Therefore, in international expansion, the decision by affiliates to open a commercial office is associated to the fact that the host country presents a positive institutional distance, when compared to the home country. We believe this happens due to the fact that the institutional characteristics of the home country, in this case Brazil, are less developed than the characteristics of the host country. Thus, incompatibility with a more developed institutional environment produces higher risk and uncertainty for affiliates, which is essentially the result of a lack of understanding when it comes to dealing with more developed institutional environments (Berry, 2006). As such, when affiliated firms decide to expand internationally, the investment takes the form of a manufacturing plant and there is a trend to choose a host country with less developed institutions than those of the home country, that is, with negative institutional distances. This is due to the groups coping well with relatively unstable institutional environments, since they develop essentially in countries with weaker institutions (Ghemawat \& Khanna, 1998; Khanna \& Palepu, 2000a). In addition, group-affiliated firms have deeprooted characteristics typical to the home market, which bolsters their development in markets with weaker institutions (Pedersen \& Stucchi, 2015). Lastly, when less developed institutions are better understood, difficulties are reduced in the host country, helping the affiliated firms to develop in that country (Håkanson \& Ambos, 2010).

\section{I Limitations and future studies}

This study was unsuccessful to cover certain aspects that deserve attention in future studies. For example, the fact that only 38 of the top 200 Brazilian groups have international operations. This issue can be addressed in both theoretical and empirical terms. Furthermore, it is important to analyze the time that lapses until 
a group-affiliated firm internationalizes, to thus use the family business group's date of foundation versus the date of its first international activity. Also, in to what extent political variables affect the type of investment (commercial office and manufacturing plant) in the host country, using data collected on political connection and tests conducted on measuring this variable in relation to the commitment of resources and institutional distance. Although this study contributed to understand the internationalization of family business groups, we believe that future studies could enhance it through enlarge the database including other countries, and providing a wider analysis of the subject. Lastly, with a larger sample, perhaps it would be possible to use more accurate statistical methods, which can check the causality among variables.

\section{References}

Aldrighi, D. M., \& Postali, F. A. (2010). Business Group in Brazil. In The Oxford handbook of business groups (pp. 353-386). New York: The Oxford University Press.

Aleksynska, M., \& Havrylchyk, O. (2013). FDI from the south: The role of institutional distance and natural resources. European Journal of Political Economy, 29.

Allison, P. . (2009). Fixed effects regression models. New York: Sage.

Becker-Ritterspach, F., \& Bruche, G. (2012). Capability creation and internationalization with business group embeddedness - the case of Tata Motors in passenger cars. European Management Journal, 30, 232- 247.

Berry, H. (2006). Shareholder valuation of foreign investment and expansion. Strategic Management JournalManagement Journal, 27(12), 1123-1140.

Borda-Reyes, A. (2012). The impact of business group diversification on emerging market multinationals: Evidence from Latin America. Innovar, 22(45), 97-110.
Chang, S.-J. (2006). Business groups in East Asia: Post-crisis restructuring and new growth. Asia Pacific Journal of Management, (23), 407-417.

Chang, S.-J., \& Hong, J. (2002). How much does the business group matter in Korea? Strategic Management Journal, 23(3), 265-274. http://doi. org/10.1002/smj.224

Costa, M. W. O., Bandeira-de-Mello, R., \& Marcon, R. (2013). A influência da conexão política na diversificação dos grupos empresariais brasileiros. Revista de Administração de Empresas, 53(4), 376-387.

Cuervo-Cazurra, A. (2006). Business Groups and Their Types. Asia Pacific Journal of Management, (23), 419-437.

Cuervo-Cazurra, A. (2008). The multinationalization of developing country MNEs: The case of Multilatinas. Journal of International Management, 14, 138-154.

Dau, L. A. (2012). Pro-Market Reforms And Developing Country Multinational Corporations. Global Strategy Journal, 2, 262-276.

Ghemawat, P., \& Khanna, T. (1998). The nature of diversified business groups: A research design and two case studies. The Journal of Industrial Economics, 46(1), 35-61. http://doi. org/10.1111/1467-6451.00060

Granovetter, M. (1994). Business Groups. In N. J. Smelser \& R. Swedberg (Eds.), The handbook of economic sociology (p. 835). Princenton University.

Guillén, M. F. (2000). Business groups in emerging economies: a resource-based view. The Academy of Management Journal, 43(3), 362-380. Retrieved from http://amj.aom.org/ content/43/3/362.short

Håkanson, L., \& Ambos, B. (2010). The antecedents of psychic distance. Journal of International Management, 16, 195-210. 
Hernandez, V., \& Nieto, M. J. (2015). The effect of the magnitude and direction of institutional distance on the choice of international entry modes. Journal of World Business, 50.

Hoskisson, R., Eden, L., Lau, C., \& Wright, M. (2000). Strategy in emerging economies. Academy of Management Journal, 43(3), 249267. Retrieved from http://www.jstor.org/ stable/10.2307/1556394

Inoue, C. F. K. V., Lazzarini, S. G., \& Musacchio, A. (2013). Leviathan as a minority shareholder: Firm-level implications of state equity purchases. Academy of Management Journal, 56(6), 17751801.

Ionascu, D., Meyer, K. E., \& Erstin, S. (2004). Institutional Distance and International Business Strategies in Emerging Economies. Retrieved from https://deepblue.lib.umich.edu/bitstream/ handle/2027.42/40114/wp728.pdf

Khanna, T., \& Palepu, K. (1997). Why Focused Strategies may be wrong in Emerging Markets. Harvard Business Review, 75(4).

Khanna, T., \& Palepu, K. (1999). Policy shocks, market intermediaries, and corporate strategy: The evolution of business groups in Chile and India. Journal of Economics and Management Strategy, 8(2), 271-310. Retrieved from http:// onlinelibrary.wiley.com/doi/10.1111/j.14309134.1999.00271.x/abstract

Khanna, T., \& Palepu, K. (2000a). Business Groups, Foreign Intermediaries, and Corporate Governance. In Concentrated Corporate Ownership (p. 387).

Khanna, T., \& Palepu, K. (2000b). Is Group Affiliation Profitable in Emerging Markets? An Analysis of Diversified Indian Business Groups. The Journal of Finance, 55(2), 867-891. Retrieved from http://onlinelibrary.wiley.com/ doi/10.1111/0022-1082.00229/abstract
Khanna, T., \& Rivkin, J. (2001). Estimating the performance effects of business groups in emerging markets. Strategic Management Journal, 74(July 2000), 45-74. Retrieved from http://onlinelibrary.wiley.com/ doi/10.1002/1097-0266(200101)22:1<45::AIDSMJ147>3.0.CO;2-F/abstract

Khanna, T., \& Yafeh, Y. (2005). Business Groups and Risk sharing around the world. Journal of Business, 78(1), 301-340.

Khanna, T., \& Yafeh, Y. (2007). Business groups in emerging markets: Paragons or parasites? Journal of Economic Literature, 45(2), 331-372. Retrieved from http://www.jstor.org/ stable/10.2307/27646796

Kostova, T. (1999). Transnational transfer of strategic organizational practices: A contextual perspective. Academy of Management Review, 24.

Kostova, T., \& Roth, K. (2002). Adoption of an organizational practice by subsidiaries of multinational corporations: institutional and relational effects. Academy of Management Journal, 1 .

Kostova, T., \& Zaheer, S. (1999). Organizational legitimacy under conditions of complexity: The case of the multinational enterprise. Academy of Management Review, 24.

Kumar, V., Stucchi, T., \& Kundu, S. (2012). Business Groups, Internationalization and Institutional Change: Evidence from India. Retrieved from https://aib.msu.edu/events/2012/ AIB2012_ConferenceProceedings.pdf

La Porta, R., Lopez-de-silanes, F., \& Shleifer, A. (1999). Corporate Ownership Around the World. Journal of Finance, $\operatorname{LIV}(2)$.

Lamin, A. (2013). Business groups as information resource: an Investigation of business group affiliation in the Indian software services industry. Academy of Management Journal, 56(5), 14871509. 
Lin, W.-T. (2014). Founder-key leaders, grouplevel decision teams, and the international expansion of business groups : Evidence from Taiwan. International Market Review, 31(2), $129-154$.

LiPuma, J. A., Newbert, S. L., \& Doh, J. P. (2013). The effect of institutional quality on firm export performance in emerging economies: a contingency model of firm age and size. Small Business Economics, 40.

Mishra, A., \& Daly, K. (2007). Effect of Quality of Institutions on Outward Foreign Direct Investment. J. Int. Trade \& Economic Development, 16(2).

Moore, C. B., Payne, G. T., Bell, R. G., \& Davis, J. L. (2015). Institutional Distance and CrossBorder Venture Capital Investment Flows. Journal of Small Business Management, 53(2), 482-500.

Morck, R. (2010). The Roddle of the great Pyramids. In A. M. Colpan, T. Hikino, \& J. R. Lincon (Eds.), The Oxford handbook of business groups (pp. 602-628). New York: The Oxford University Press.

Morck, R., Shleifer, A., \& Vishny, R. (1988). Management Ownership and Market Valuation - An Empirical Evidence. Journal of Financial Economics, 20, 293-315.

Morck, R., \& Yeung, B. (2003). Agency Problem in Large Family Business Gorups. ENTREPRENEURSHIP THEORY and PRACTICE, 367-382.

Mudambi, R., \& Navarra, P. (2002). Institutions and internation business: a theoretical overview. International Business Review, 11(6), 635-646.

North, D. C. (1990). Institutions, Institutional Change and Economic Performance.

Pedersen, T., \& Stucchi, T. (2015). Business groups, institutional transition, and the internationalization of firms from emerging economies. In A. Cuervo-Cazurra \& $\mathrm{R}$. Ramamurti (Eds.), Understanding Multinationals from Emerging Markets (1st ed., pp. 224-241). Cambridge: Cambridge University Press.

Schneider, B. R. (2009). A comparative political economy of diversified business groups, or how states organize big business. Review of International Political Economy, 16(2), 178-201. http://doi.org/10.1080/09692290802453713

Slangen, A. H. L., \& Tulder, R. J. M. van. (2009). Cultural distance, political risk, or governance quality? Towards a more accurate conceptualization and measurement of external uncertainty in foreign entry mode research. International Business Review, 18, 276-291.

Vernon, R. (1979). The product cycle hypothesis in a new international environment. Oxford Bulletin of Economics and Statistics, 41(4), 255-267.

Williamson, O. (1981). The Economics of Organization: The transaction costs approach. American Journal of Sociology, 87(3), 548-577.

Williamson, O. (2000). The new isntitutional Economics: Taking Stock, Looking Ahead. Journal of Economic Literature, 38(3).

Xavier, W. G., Marcon, R., \& Bandeira-deMello, R. (2013). Institutional Environment and Business Groups Resilience in Brazil. Journal of Business Research.

Xu, D., \& Shenkar, O. (2002). Institutional distance and the multinational enterprise. Academy of Management Review, 27.

Yang, X., Jiang, Y., Kang, R., \& Ke, Y. (2009). A comparative analysis of the internationalization of Chinese and Japanese firms. Asia Pacific Journal of Management, 26(1), 141-162.

Yaprak, A., \& Karademir, B. (2010). The internationalization of emerging market business 
groups: an integrated literature review. International Market Review, 27(2), 245 - 262. http://doi.org/ http://dx.doi.org/10.1108/02651331011037548

Yiu, D. W., Lu, Y., Bruton, G. D., \& Hoskisson, R. (2007). Review Paper Business Groups : An Integrated Model to Focus Future Research. Journal of Management Studies, 44(8), 1551-1579.
Zaheer, S., \& Mosakowski, E. (1997). The Dynamics of the Liability of Foreignness: A Global Study of Survival in Financial Services. Strategic Management Journal, 18, 439-464.

\section{About the authors:}

1. Marina A. B. Gama, MSc in Strategy, Getulio Vargas Foundation, Sao Paulo Business Administration School - EAESP, Brazil. Email: abgama@gmail.com

2. Jeferson Lana, MSc in Management, University of Vale do Itajaí - Univali, Brazil.

Email: jeff@rovian.com.br

3. Cyntia Vilasboas Calixto, MSc in Management, University of Vale do Rio dos Sinos - Unisinos, Brazil. Email: cyntiacalixto@gmail.com

4. Rodrigo Bandeira-de-Mello, PhD in Production Engineering, Federal University of Santa Catarina UFSC, Brazil. Email: rodrigo.mello@fgv.br

\section{Contributions of each author:}

\begin{tabular}{|c|c|c|c|c|}
\hline Contribution & Marina Gama & Jeferson Lana & Cyntia Calixto & $\begin{array}{c}\text { Rodrigo } \\
\text { Bandeira-de-Mello }\end{array}$ \\
\hline 1. Definition of research problem & $\sqrt{ }$ & $\sqrt{ }$ & $\sqrt{ }$ & $\sqrt{ }$ \\
\hline $\begin{array}{l}\text { 2. Development of hypotheses or research questions } \\
\text { (empirical studies ) }\end{array}$ & $\sqrt{ }$ & $\sqrt{ }$ & $\sqrt{ }$ & \\
\hline $\begin{array}{l}\text { 3. Development of theoretical propositions } \\
\text { (theoretical work) }\end{array}$ & $\sqrt{ }$ & & $\sqrt{ }$ & \\
\hline 4. Theoretical foundation / Literature review & $\sqrt{ }$ & & $\sqrt{ }$ & \\
\hline 5. Definition of methodological procedures & & $\sqrt{ }$ & & \\
\hline 6. Data collection & $\sqrt{ }$ & $\sqrt{ }$ & $\sqrt{ }$ & \\
\hline 7. Statistical analysis & & $\sqrt{ }$ & & \\
\hline 8. Analysis and interpretation of data & & $\sqrt{ }$ & & \\
\hline 9. Critical revision of the manuscript & & $\sqrt{ }$ & $\sqrt{ }$ & $\sqrt{ }$ \\
\hline 10. Manuscript writing & $\sqrt{ }$ & $\sqrt{ }$ & $\sqrt{ }$ & $\sqrt{ }$ \\
\hline
\end{tabular}

